\title{
Double PCL sign on sagittal MRI of the knee
}

\author{
Omar Hadidi, Prasad Ellanti, Marc Lincoln, Niall Hogan
}

Department of Orthopaedics, St. James's Hospital, Dublin, Ireland

\section{Correspondence to}

Dr Omar Hadidi, hadidio@tcd.ie

Accepted 30 September 2017

\section{DESCRIPTION}

A 24-year-old male presented with left knee pain and swelling after a fall sixweeks earlier playing football. Clinical examination revealed an antalgic gait and a moderate left knee effusion with tenderness along the medial joint line. Anterior drawer and Lachman tests were positive, suggesting an anterior cruciate ligament (ACL) injury. An MRI scan performed shortly after the injury revealed a large joint effusion and significant acute bone oedema involving the medial tibial condyle. While the posterior cruciate ligament (PCL) was intact, the ACL was elongated and suspicious for an intrasubstance tear. A bucket-handle tear of the medial meniscus was observed with the free fragment seen within the intercondylar notch. This gave rise to the double PCL sign on sagittal view. The patient underwent arthroscopic ACL reconstruction with a hamstring graft, and the medial meniscus was excised as it was unrepairable.

The 'double PCL' sign refers to the anterosuperior displacement of a bucket-handle medial meniscal tear. ${ }^{1}$ The torn fragment occupies an anteroinferior position relative to the PCL, producing an apparent second, smaller PCL (figure 1 , figure 2 ). ${ }^{2}$ The double PCL sign has been shown to have a high specificity for meniscal tears when noted on MRI. It is important to note, however, that there are normal variants of anatomy-in particular those of the ligaments of Humphrey and Wrisberg-which can give rise to a similar appearance. ${ }^{3}$

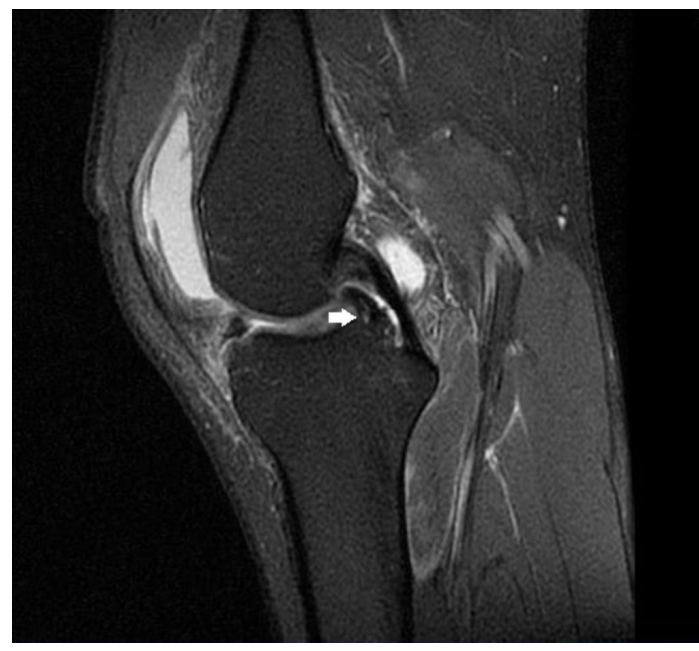

Figure 1 Sagittal MRI of the left knee. The torn medial meniscus can be observed as a second, smaller posterior cruciate ligament $(\mathrm{PCL})$ just anteroinferior to the $\mathrm{PCL}$.

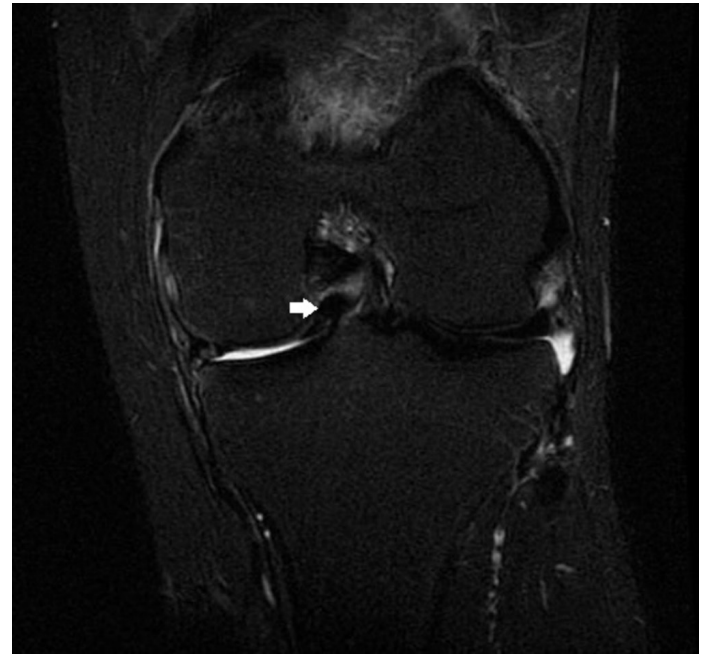

Figure 2 Coronal MRI of the left knee. The torn medial meniscus is demonstrated within the intercondylar notch.

\section{Patient's perspective}

It all began three years ago when I sustained an injury while playing football. It was very painful and felt like there was an electric shock in my knee. After surgery, I started physiotherapy and was given exercises to do. My aim always was to go back to playing sports. In addition to physiotherapy, I tried massage and salt water therapy. The most important thing was to believe in myself and work hard in order to get back to where I was before. After three years, I can say that I'm back to playing football and confident in my legs once again.

Learning points

- The double posterior cruciate ligament (PCL) sign is seen on sagittal MRI and can signify a displaced meniscal tear, typically that of the medial meniscus.

- This sign is produced due to the appearance of a bucket-handle tear on sagittal MRI as an apparent second, smaller PCL.

Contributors $\mathrm{OH}$ and PE wrote the manuscript. ML edited the manuscript. NH supervised the writing of the manuscript and treated the patient.

Competing interests None declared.

Patient consent Obtained.

Provenance and peer review Not commissioned; externally peer reviewed. 
(c) BMJ Publishing Group Ltd (unless otherwise stated in the text of the article) 2017. All rights reserved. No commercial use is permitted unless otherwise expressly granted.

\section{REFERENCES}

1 Weiss KL, Morehouse HT, Levy IM. Sagittal MR images of the knee: a low-signal band parallel to the posterior cruciate ligament caused by a displaced bucket-handle tear. AJR Am J Roentgenol 1991;156:117-9.

Copyright 2017 BMJ Publishing Group. All rights reserved. For permission to reuse any of this content visit http://group.bmi.com/group/rights-licensing/permissions.

BMJ Case Report Fellows may re-use this article for personal use and teaching without any further permission.

Become a Fellow of BMJ Case Reports today and you can:

- Submit as many cases as you like

- Enjoy fast sympathetic peer review and rapid publication of accepted articles

- Access all the published articles

Re-use any of the published material for personal use and teaching without further permission

For information on Institutional Fellowships contact consortiasales@bmjgroup.com

Visit casereports.bmj.com for more articles like this and to become a Fellow
2 Camacho MA. The double posterior cruciate ligament sign. Radiology 2004;233:503-4.

3 Venkatanarasimha N, Kamath A, Mukherjee K, et al. Potential pitfalls of a double PCL sign. Skeletal Radiol 2009:38:735-9. 